\title{
Pengontrolan Kecepatan Aliran Vortex Berbasis Arduino Sebagai Metoda Pemisah Campuran Serbuk Tembaga dan Aluminium
}

\author{
Fico Trianda Ravelli and Firman Ridwan \\ Jurusan Teknik Mesin, Fakultas Teknik, Universitas Analas, Kampus Limau Manis, Kecamatan Pauh, Kota Padang, Sumatera Barat 25163, Indonesia
}

INFORMASI ARTIKEL

Sejarah Artikel:

Diterima Redaksi: 08 Februari 2019

Revisi Akhir: 22 Maret 2019

Diterbitkan Online: 29 April 2019

\section{KATA KUNCI}

Flow Rate, separation, water, vortex flow

KORESPONDENSI

E-mail: firmanridwan@ft.unand.ac.id

\begin{abstract}
A B S T R A C T
Several methods have been developed to separate gold from alluvial using the principle of density. Density is used as a basic concept in material separation. One of the supporting methods that can be used to utilize the vortex flow as a separation medium. With vortex flow, two materials of different density can be separated through lift force. This study aims to determine the effect of vortex flow velocity on its ability to separate two different types of density material. Aluminum and Copper powders are used as test materials with a powder size of 18-200 mesh. The tests are carried out with a variation of 10 flow rates with water as a fluid. The results showed that Aluminum and Copper can be optimally separated at the flow rate (165.25-167.77) $\mathrm{ml} / \mathrm{s}$. While for the most effective effectiveness of $\mathrm{Al}$ separation is the flow rate $(163.22-168.87) \mathrm{ml} / \mathrm{s}$ and copper separation at the flow rate $(83.5-85) \mathrm{ml} / \mathrm{s}$.
\end{abstract}

\section{PENDAHULUAN}

Alat pemisah material banyak digunakan dalam berbagai industri, baik itu industri manufaktur maupun industri pengolahan limbah. Alat pemisah material banyak ditemukan dalam berbagai manfaat, seperti memisahkan logam dengan logam, logam dengan non logam, ataupun antara non logam dengan non logam. Alat tersebut sangat bermanfaat dalam berbagai keperluan, seperti pemilahan sampah, pemilahan suatu senyawa, atau pada material yang telah tercampur sehingga membutuhkan perlakuan khusus untuk memisahkannya. Alat pemisah juga dapat kita jumpai pada proses penambangan emas, seperti yang digunakan dalam penambangan emas, dimana proses yang dilakukan ialah memisahkan emas dengan pasir atau alluvial. Beberapa alat telah dikembangkan untuk dapat memisahkan emas dari alluvial dengan menggunakan prinsip massa jenis. Massa jenis dijadikan sebagai konsep dasar dalam pemisahan material. Salah satu metoda penunjang yang bisa digunakan ialah dengan memanfaatkan aliran vortex sebagai media separasi. Dengan aliran vortex, melalui gaya angkat yang dihasilkannya, dapat memisahkan dua material yang berbeda nilai massa jenisnya. Dengan kondisi tersebut, penulis merasa perlu untuk mengetahui pengaruh aliran vortex terhadap efektifitas separasi yang didasari pada variasi flow rate air sehingga secara umum dapat meningkatkan kemampuan suatu alat pertambangan dalam memperoleh material khususnya yang berukuran mikro (serbuk).

\subsection{Arduino Uno}

Arduino Uno adalah board mikrokontroler berbasis ATMega328. Memiliki 14 pin input dari output digital dimana 6 pin input tersebut dapat digunakan sebagai output PWM (Pulse Widht Modulation) dan 6 pin input analog, $16 \mathrm{MHz}$ 
osilator kristal, koneksi USB, jack power, ICSP header, dan tombol reset [1]. Untuk mendukung mikrokontroler agar dapat digunakan, cukup hanya menghubungkan board Arduino Uno ke komputer dengan menggunakan kabel USB dan AC adaptor sebagai suplay atau baterai untuk menjalankannya. Kelebihan Arduino diantaranya adalah tidak perlu perangkat chip programmer karena didalamnya sudah ada bootloader yang akan menangani upload program dari komputer, Arduino sudah memiliki sarana komunikasi USB, sehingga pengguna laptop yang tidak memiliki port serial/RS323 bisa menggunakannya. bahasa pemrograman relatif mudah karena software Arduino dilengkapi dengan kumpulan library yang cukup lengkap, dan Arduino memiliki modul siap pakai (shield) yang bisa ditancapkan pada board Arduino. Misalnya shield GPS, Ethernet, SD Card, dan lain-lain.

\subsection{Separasi Mekanik}

Separasi adalah pemisahan komponen-komponen dari suatu campuran sehingga menjadi fraksi-fraksi individual. Banyak metode yang diciptakan untuk melaksanakan pemisahan (separasi), dan ada beberapa satuan operasi yang dikhususkan untuk itu.

Prosedur pemisahan campuran dapat dibagi menjadi dua golongan:

1. Golongan pertama meliputi metode-metode yang menggunakan prinsip difusi yang meliputi perubahan fase atau perpindahan bahan dari satu fase ke fase yang lain.

2. Golongan kedua meliputi metode yang dinamakan separasi mekanik yang digunakan untuk memisahkan partikel zat padat atau tetesan zat cair.

Separasi mekanik digunakan untuk campuran heterogen, bukan larutan homogen. Terutama untuk partikel yang berukuran lebih besar dari $1 \mu \mathrm{m}$. teknik-teknik ini didasarkan atas perbedaan fisika dari partikel tersebut, baik dimensi, massa, densitas.

\subsection{Metode Pengendapan Differensial}

Metode pengendapan differensial memanfaatkan perbedaan kecepatan terminal dari kedua partikel yang densitasnya berbeda. Dalam pengendapan differensial, baik partikel ringan maupun partikel berat akan mengendap melalui medium yang sama. Misalnya : partikel-partikel dua bahan $\boldsymbol{A}$ dan $\boldsymbol{B}$ yang mengendap melalui medium yang mempunyai densitas $\rho$. Diumpamakan diantara kedua bahan itu $\boldsymbol{A}$ adalah bahan yang lebih berat; misalnya komponen $\boldsymbol{A}$ adalah galena (gravitasi spesifik $=7,5$ ) dan komponen $\boldsymbol{B}$ kuarsa (gravitasi spesifik $=2,65)$. kecepatan terminal partikel yang ukurannya $D_{P}$ dan densitasnya $\rho_{p}$ yang mengendap karena gravitasi didalam medium yang densitasnya $\rho$ diberikan dalam suatu persamaan untuk pengendapan pada hukum stoke. Persamaan ini dapat dituliskan, untuk partikel galena yang densitasnya $\rho_{P a}$ dan diameternya $D_{P A}$, sebagai;

$\mathrm{u}_{\mathrm{tA}}=\frac{g D_{p A}^{2}\left(\rho_{p A}-\rho\right)}{18 \mu}$

Untuk partikel kuarsa yang densitasnya $\rho_{\mathrm{pB}}$ dan diameternya $\mathrm{D}_{\mathrm{pB}}$,

$\mathrm{u}_{\mathrm{tB}}=\frac{g D_{p B}^{2}\left(\rho_{p B}-\rho\right)}{18 \mu}$

Untuk partikel yang kecepatan pengendapannya sama, $\mathrm{u}_{\mathrm{tA}}=\mathrm{u}_{\mathrm{tB}}$, sehingga,

$\frac{D_{p A}}{D_{p B}}=\sqrt{\frac{\rho_{p B}-\rho}{\rho_{p A}-\rho}}$

Untuk pengendapan dalam hukum Newton, diameter partikel yang pengendapannya sama, dari persamaan $\mathrm{u}_{\mathrm{t}}=1.75 \sqrt{\frac{g D p\left(\rho_{P}-\rho\right)}{\rho}}$ (hukum Newton untuk partikel yang lebih besar jatuh dalam fluida dengan $\mu$ rendah) dihubungkan oleh persamaan

$$
\frac{D_{p A}}{D_{p B}}=\frac{\rho_{p B}-\rho}{\rho_{p A}-\rho}
$$


Pengertian rasio diameter pengendapan sama ini di dalam proses separasi terlihat pada Gambar 1.

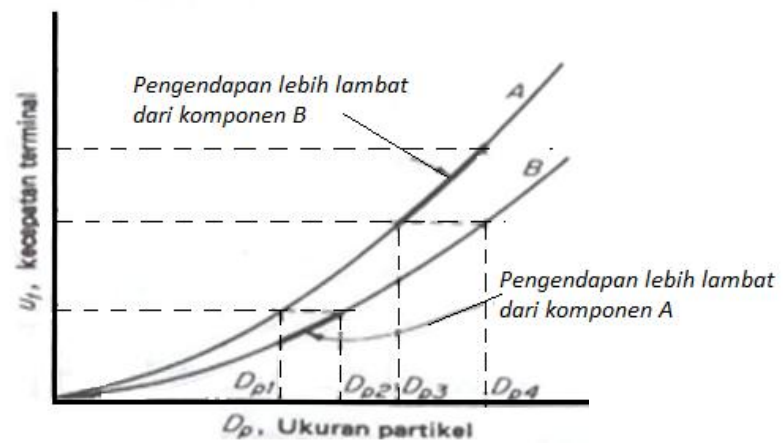

Gambar 1. Partikel-Partikel yang Pengendapnya Sama

Dimana kurva $u_{\mathrm{t}}$ vs $\mathrm{D}_{\mathrm{p}}$ digambarkan grafiknya untuk komponen $A$ dan $B$, pada pengendapan hukum Stoke. Misalkan diameter kedua bahan itu berkisar antara $D_{\mathrm{p} 1}$ dan $\mathrm{D}_{\mathrm{p} 4}$ pada sumbu ukuran partikel. Jadi, semua partikel komponen ringan $B$ yang diameternya terletak antara $\mathrm{D}_{\mathrm{p} 1}$ dan $\mathrm{D}_{\mathrm{p} 2}$ akan mengendap lebih lambat dari partikel berat $A$ dan bisa didapatkan sebagai fraksi murni. Akan tetapi, setiap partikel berat $A$ yang diameternya terletak antara $\mathrm{D}_{\mathrm{p} 3}$ dan $\mathrm{D}_{\mathrm{p} 4}$ mengendap lebih cepat dari partikel berat $\mathrm{B}$ dan bisa juga didapatkan sebagai fraksi murni. Sedangkan setiap partikel ringan yang diameternya antara $\mathrm{D}_{\mathrm{p} 2}$ dan $\mathrm{D}_{\mathrm{p} 4}$ akan mengendap dengan kecepatan yang sama seperti partikel $A$ yang mempunyai ukuran antara $D_{p 1}$ dan $\mathrm{D}_{\mathrm{p} 3}$ dan semua partikel yang ukurannya demikian akan membentuk fraksi campuran.

Persamaan (3) dan (4) menunjukkan bahwa ketajaman pemisahan dapat diperbaiki jika densitas medium yang digunakan lebih tinggi. Dari gambar partikel yang pengendapnya sama, jelas pula bahwa fraksi campuran dapat dikurangi atau dihilangkan sama sekali dengan mengatur ukuran umpan secara lebih ketat. Misalnya, jika ukuran partikel umpan adalah antara $\mathrm{D}_{\mathrm{p} 3}$ dan $\mathrm{D}_{\mathrm{p} 4}$ dalam gambar tersebut, kita bisa mendapatkan pemisahan total.

\section{METODOLOGI}

\subsection{Perangkat Pengujian}

Perangkat pengujian yang digunakan dalam penelitian ini adalah alat separator yang dioperasikan menggunakan pompa serta memanfaatkan bukaan katup. Perangkat pengujian tersebut terdiri dari : Sensor Kecepatan Aliran Fluida, Arduino Uno, Tabung Acrylic, Ball Valve, Timbangan Digital dan Pompa.

\subsection{Material Uji}

Material uji yang digunakan dalam pengujian kali ini ialah serbuk tembaga dan aluminium dengan

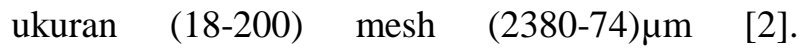
Penggunaan tembaga dan aluminium didasari atas perbedaan massa jenis kedua material tersebut yang cukup jauh, sehingga memudahkan dalam melaksanakan pengujian. Pemilihan tembaga dan aluminium juga didasari atas kemudahan dalam memperoleh kedua material tersebut. Gambar 2 menunjukkan material uji yang digunakan.

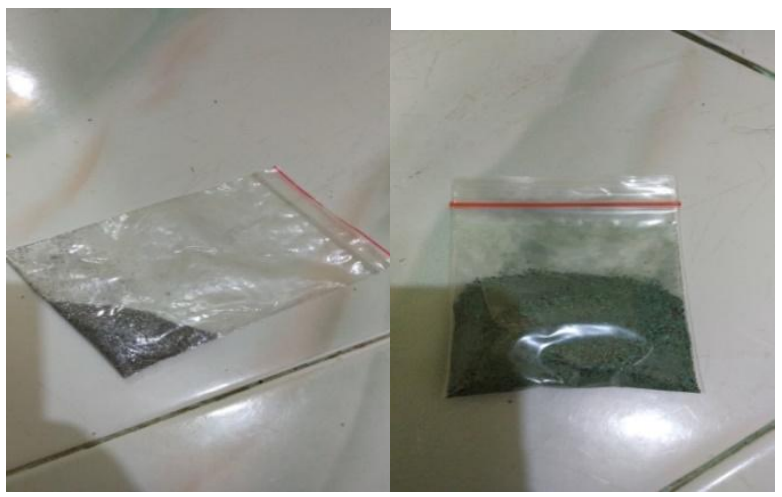

(a)

(b)

Gambar 2. (a) Serbuk Al (b) Serbuk Cu

\subsection{Skema Alat}

Gambar 3 menunjukkan skema alat yang digunakan dalam pengujian. Pengujian dilakukan pada rentang waktu pagi hingga sore hari, sehingga memudahkan dalam mengamati fenomena separasi serta mengamati profil aliran vortex yang terbentuk. 


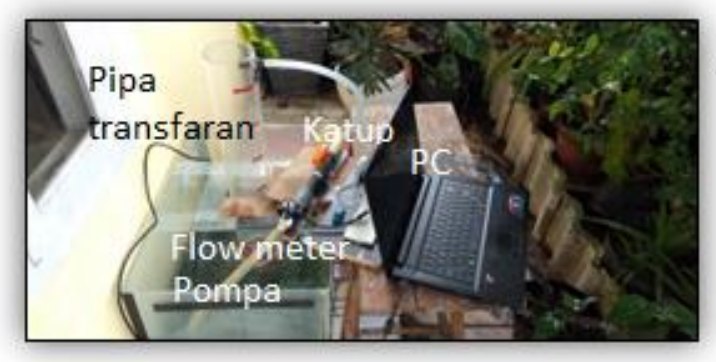

Gambar 3. Skema Alat

\subsection{Rangkaian Kontrol}

Rangkaian kontrol merupakan tempat pengontrolan kecepatan aliran air melalui bukaan stop kran dan record kecepatan aliran air melalui water flow sensor yang ditampilkan oleh LCD. Beberapa komponen kendali dihubungkan dengan jumper. Gambar 4 menunjukkan skema rangkaian kontrol yang digunakan.

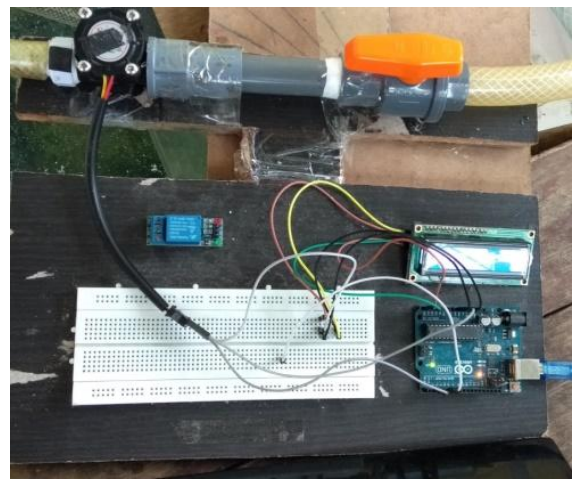

Gambar 4. Skema Rangkaian Kontrol

\subsection{Prinsip Kerja}

Proses separasi dilakukan dengan dua tahap. Tahap pertama dilakukan untuk mengetahui pengaruh perbedaan kecepatan aliran air terhadap efektifitas separasi tembaga dan pada tahap kedua dilakukan untuk mengetahui pengaruh perbedaan kecepatan aliran air terhadap efektifitas separasi aluminium. Proses separasi dilakukan dengan terlebih dahulu mengukur massa awal serbuk, kemudian setelah proses pengukuran dilakukan, maka dilakukanlah record data awal serbuk untuk nanti dibandingkan dengan massa serbuk yang tersisa di dasar tabung separasi sebagai tolak ukur nilai efektifitas separasi. Setelah massa awal serbuk diperoleh, proses pengujian dilakukan dengan menghidupkan pompa untuk mengalirkan air ke tabung separasi. Sebelum aliran air sampai di tabung separasi, terlebih dahulu aliran air melewati rangkaian kontrol untuk mengetahui nilai kecepatan aliran air dan mengatur bukaan katup. Pada rangkaian kontrol terdapat stop kran, water flow sensor, arduino dan LCD. Arduino menerima input dari water flow sensor berupa nilai kecepatan aliran air dan LCD bertindak sebagai aktuator yang akan menampilkan nilai kecepatan aliran tersebut. Kemudian setelah air sampai di tabung separasi dan terbentuk aliran vortex dengan perkiraan ketinggian air berkisar antara $12 \mathrm{~cm}$ sampai dengan $20 \mathrm{~cm}$ dari dasar tabung separasi, serbuk $\mathrm{Cu}$ atau $\mathrm{Al}$ dimasukkan ke tabung separasi. Setelah serbuk dimasukkan, air dibiarkan mengalir hingga sampai ke bagian outlet. Setelah air keluar melalui saluran outlet dan mengalir hingga sampai di wadah penampungan air (reservoar), pompa dimatikan dan air yang berada di tabung separasi dikeringkan, dan ditimbang massa serbuk $\mathrm{Cu}$ atau $\mathrm{Al}$ yang tersisa pada dasar tabung separasi.

Pengujian ini dilakukan dengan variasi 10 bukaan katup, atau 10 kecepatan aliran air. Dengan tiap posisi bukaan katup dilakukan 3 kali percobaan. Skema alur pengujian dapat dilihat pada Gambar 5.

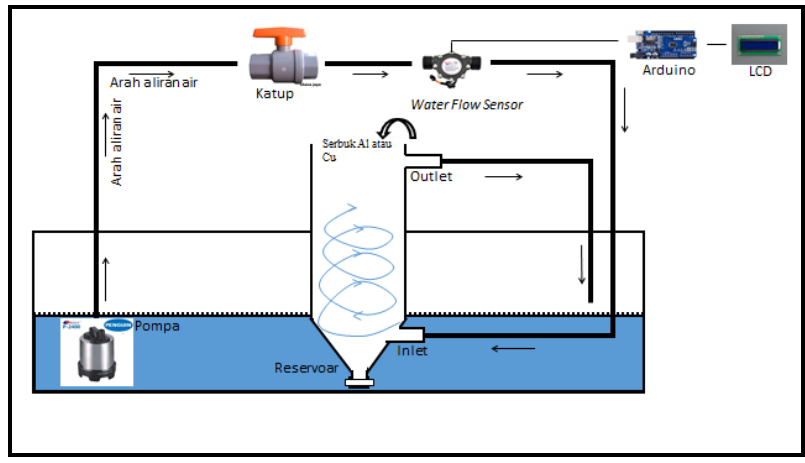

Gambar 5. Bagan Pengujian

\section{HASIL DAN PEMBAHASAN}

\subsection{Data Separasi Tembaga}

Data separasi tembaga merupakan data massa serbuk tembaga dan data kecepatan aliran air pada saat proses separasi yang dilakukan terhadap tembaga. Data massa serbuk tembaga diperoleh melalui pengukuran massa awal serbuk tembaga dan pengukuran massa akhir dari serbuk yang tenggelam di dasar tabung separasi. Data massa 
serbuk tembaga yang ditampilkan berdasarkan jenis pompa yang digunakan. Tabel 1 menunjukkan data yang didapatkan melalui penggunaan pompa 1 , sementara Tabel 2 menunjukkan data yang didapatkan melalui penggunaan pompa 2 .

Tabel 1. Data Massa Serbuk Tembaga Edisi 1 (Menggunakan Pompa 1)

\begin{tabular}{|c|c|c|c|}
\hline Posisi & $\begin{array}{c}\text { Data Awal } \\
\text { (gram) }\end{array}$ & $\begin{array}{c}\text { Hasil } \\
\text { (gram) }\end{array}$ & $\begin{array}{c}\text { Kecepatan } \\
(\mathrm{ml} / \mathrm{s})\end{array}$ \\
\hline $\mathrm{CuF} 1$ & 0.26 & 0.26 & 134.73 \\
\hline $\mathrm{CuF} 2$ & 0.26 & 0.21 & 127.06 \\
\hline $\mathrm{CuF} 3$ & 0.39 & 0.27 & 122.91 \\
\hline $\mathrm{Cu} 11$ & 0.29 & 0.28 & 115.63 \\
\hline $\mathrm{Cu} 12$ & 0.34 & 0.26 & 126.95 \\
\hline $\mathrm{Cu} 13$ & 0.19 & 0.12 & 121.31 \\
\hline $\mathrm{Cu} 21$ & 0.24 & 0.22 & 105.25 \\
\hline $\mathrm{Cu} 22$ & 0.19 & 0.12 & 98.12 \\
\hline $\mathrm{Cu} 23$ & 0.35 & 0.32 & 94.55 \\
\hline $\mathrm{Cu} 31$ & 0.27 & 0.35 & 73.26 \\
\hline $\mathrm{Cu} 32$ & 0.46 & 0.61 & 85 \\
\hline $\mathrm{Cu} 33$ & 0.26 & 0.85 & 84.21 \\
\hline $\mathrm{Cu} 41$ & 0.13 & 0.15 & 45.14 \\
\hline $\mathrm{Cu} 42$ & 0.16 & 0.15 & 39.16 \\
\hline $\mathrm{Cu} 43$ & 0.26 & 2.72 & 39.16 \\
\hline
\end{tabular}

Data massa serbuk tembaga didapatkan dengan 5 variasi posisi bukaan katup dengan setiap variasi bukaan katup dilakukan 3 kali percobaan. Sementara untuk data kecepatan aliran air didapatkan melalui record data oleh sensor kecepatan aliran air. Kecepatan aliran air yang melalui tabung separasi di record, agar perbandingan nilai kecepatan aliran air dengan efektifitas separasi bisa didapatkan. Kecepatan aliran air yang ditampilkan merupakan rata-rata dari kecepatan aliran air yang melewati tabung separasi.
Tabel 2. Data Massa Serbuk Serbuk Tembaga Edisi 2 (Menggunakan Pompa 2)

\begin{tabular}{|c|c|c|c|}
\hline Posisi & $\begin{array}{c}\text { Data Awal } \\
\text { (gram) }\end{array}$ & $\begin{array}{c}\text { Hasil } \\
\text { (gram) }\end{array}$ & $\begin{array}{c}\text { Kecepatan } \\
(\mathrm{ml} / \mathrm{s} \text { ) }\end{array}$ \\
\hline $\mathrm{CuF} 1$ & 0.41 & 0.49 & 183.85 \\
\hline $\mathrm{CuF} 2$ & 0.52 & 0.35 & 180.25 \\
\hline $\mathrm{CuF3}$ & 0.53 & 0.75 & 181.1 \\
\hline $\mathrm{Cu} 11$ & 0.36 & 0.36 & 181.1 \\
\hline $\mathrm{Cu} 12$ & 0.31 & 0.19 & 150.5 \\
\hline $\mathrm{Cu} 13$ & 0.5 & 0.89 & 177.77 \\
\hline $\mathrm{Cu} 21$ & 0.33 & 0.16 & 162.55 \\
\hline $\mathrm{Cu} 22$ & 0.5 & 0.5 & 167.91 \\
\hline $\mathrm{Cu} 23$ & 0.5 & 0.41 & 165.3 \\
\hline $\mathrm{Cu} 31$ & 0.35 & 0.19 & 143.36 \\
\hline $\mathrm{Cu} 32$ & 0.5 & 0.48 & 156.61 \\
\hline $\mathrm{Cu} 33$ & 0.3 & 0.28 & 144 \\
\hline $\mathrm{Cu} 41$ & 0.43 & 0.51 & 83.5 \\
\hline $\mathrm{Cu} 42$ & 0.45 & 0.41 & 78.61 \\
\hline $\mathrm{Cu} 43$ & 0.33 & 0.59 & 81.55 \\
\hline
\end{tabular}

\subsection{Data Separasi Alumunium}

Data separasi alumunium merupakan data massa serbuk alumunium dan data kecepatan aliran air pada saat proses separasi yang dilakukan terhadap alumunium. Data massa serbuk alumunium merupakan data yang diperoleh melalui pengukuran massa awal serbuk alumunium dan pengukuran massa akhir dari serbuk yang tenggelam di dasar tabung separasi. Data yang ditampilkan berdasarkan jenis pompa yang digunakan. Tabel 3 menunjukkan data yang didapatkan melalui penggunaan pompa 1, sementara Tabel 4 menunjukkan data yang didapatkan melalui penggunaan pompa 2. Data separasi alumunium didapatkan dengan 5 variasi posisi bukaan katup dengan setiap variasi bukaan katup dilakukan 3 kali percobaan. 
Tabel 3. Hasil Separasi Serbuk Tembaga Edisi 1 (Menggunakan Pompa 1)

\begin{tabular}{|c|c|c|c|}
\hline Posisi & $\begin{array}{c}\text { Data Awal } \\
\text { (gram) }\end{array}$ & $\begin{array}{c}\text { Hasil } \\
\text { (gram) }\end{array}$ & $\begin{array}{c}\text { Kecepatan } \\
(\mathrm{ml} / \mathrm{s})\end{array}$ \\
\hline AlF1 & 0.14 & 0.01 & 123.88 \\
\hline AlF2 & 0.1 & 0.02 & 115.77 \\
\hline AlF3 & 0.05 & 0.05 & 133.18 \\
\hline Al11 & 0.1 & 0.03 & 122.56 \\
\hline Al12 & 0.1 & 0.04 & 108.73 \\
\hline Al13 & 0.16 & 0.16 & 110.11 \\
\hline $\mathrm{Al} 21$ & 0.17 & 0.16 & 92.47 \\
\hline $\mathrm{Al} 22$ & 0.13 & 0.01 & 92.43 \\
\hline $\mathrm{Al} 23$ & 0.25 & 0.06 & 92.95 \\
\hline Al31 & 0.14 & 0.1 & 74.23 \\
\hline $\mathrm{Al} 32$ & 0.26 & 0.23 & 72.46 \\
\hline Al33 & 0.14 & 0.16 & 74 \\
\hline Al41 & 0.18 & 0.36 & 41.6 \\
\hline Al42 & 0.26 & 0.18 & 42.83 \\
\hline A143 & 0.31 & 0.2 & 41.6 \\
\hline
\end{tabular}

Tabel 4. Hasil Separasi Serbuk Tembaga Edisi 2 (Menggunakan Pompa 2)

\begin{tabular}{|c|c|c|c|}
\hline Posisi & $\begin{array}{c}\text { Data Awal } \\
\text { (gram) }\end{array}$ & $\begin{array}{c}\text { Hasil } \\
\text { (gram) }\end{array}$ & $\begin{array}{c}\text { Kecepatan } \\
\text { (ml/s) }\end{array}$ \\
\hline $\mathrm{AlF} 1$ & 0.12 & 0.1 & 173.57 \\
\hline $\mathrm{AlF} 2$ & 0.09 & 0.08 & 183.09 \\
\hline $\mathrm{AlF3}$ & 0.17 & 0.08 & 186.66 \\
\hline $\mathrm{A} 111$ & 0.1 & 0.03 & 163.22 \\
\hline $\mathrm{A} 112$ & 0.12 & 0.04 & 175.44 \\
\hline $\mathrm{A} 113$ & 0.14 & 0.06 & 164.66 \\
\hline $\mathrm{A} 121$ & 0.1 & 0.14 & 166.5 \\
\hline $\mathrm{A} 122$ & 0.14 & 0.05 & 168.87 \\
\hline $\mathrm{A} 123$ & 0.19 & 0.09 & 169 \\
\hline $\mathrm{A} 131$ & 0.16 & 0.07 & 147.55 \\
\hline $\mathrm{A} 132$ & 0.23 & 0.21 & 147.77 \\
\hline $\mathrm{Al} 33$ & 0.25 & -0.01 & 146.9 \\
\hline $\mathrm{A} 141$ & 0.13 & 0.12 & 84.85 \\
\hline $\mathrm{A} 142$ & 0.2 & 0.11 & 89 \\
\hline $\mathrm{A} 143$ & 0.12 & 0.04 & 88.2 \\
\hline
\end{tabular}

\subsection{Perhitungan Efektifitas Separasi Tembaga}

Persamaan (5) digunakan untuk memperoleh nilai efektifitas separasi dari tembaga.

$\eta_{s C u}=\frac{\text { Hasil }}{\text { DataAwal }} \times 100 \%$

Keterangan :

$\eta_{s c u} \quad=$ Efektifitas Separasi $\mathrm{Cu}$
Hasil
= Massa Tembaga Setelah Proses Separasi
Data Awal = Massa Awal Tembaga Sebelum Proses Separasi

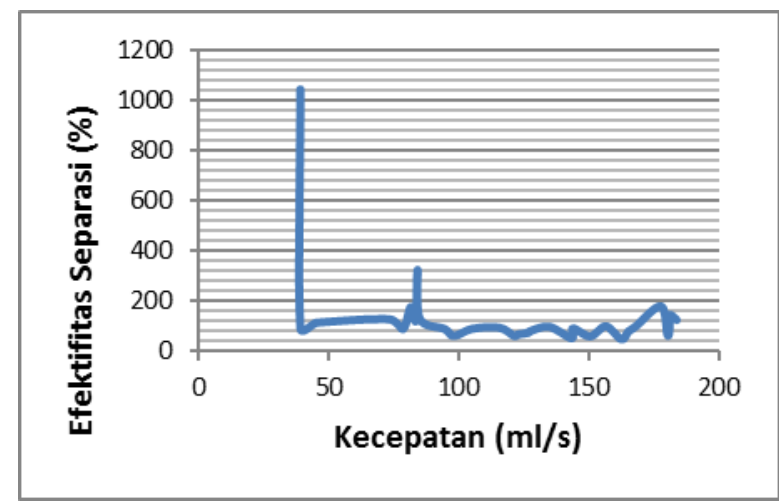

Gambar 6. Efektifitas Tembaga Terhadap

Kecepatan Aliran Vortex

Gambar 6. dan Gambar 7. menunjukkan bahwa persentase efektifitas separasi tembaga tidak memiliki korelasi terhadap kecepatan aliran vortex, yang menandakan bahwa kecepatan aliran vortex tidak mempengaruhi efektifitas separasi tembaga. Hal ini terjadi bisa dikarenakan oleh pengukuran material uji yang belum akurat.

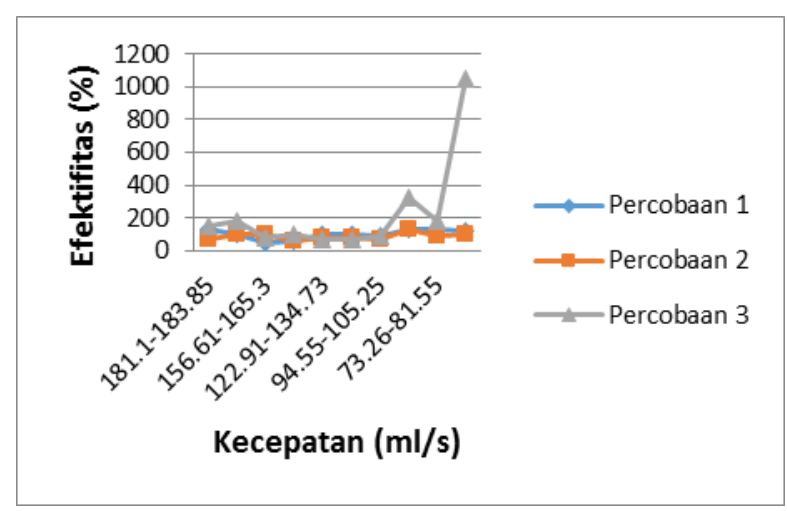

Gambar 7. Efektifitas Separasi Tembaga Pada Semua Percobaan

\subsection{Perhitungan Efektifitas Separasi Alumunium}

Persamaan (6) digunakan untuk menghitung nilai efektifitas separasi aluminium.

$$
\eta_{s A l}=\left[\frac{\text { DataAwal-Hasil }}{\text { DataAwal }} \times 100 \%\right]
$$




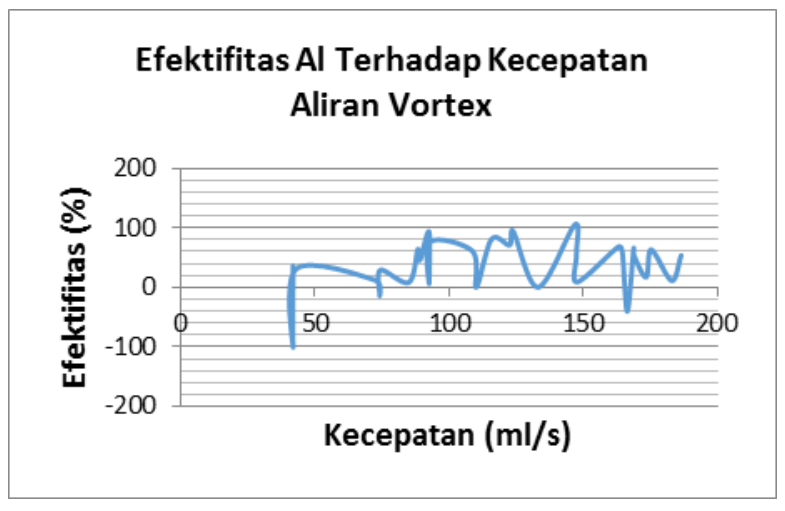

Gambar 8. Efektifitas Aluminium Terhadap Kecepatan Aliran Vortex

Gambar 8. dan Gambar 9 juga menunjukkan bahwa tidak adanya korelasi antara kecepatan aliran vortex dengan efektifitas separasi aluminium, karena tidak terlihat adanya kaitan secara grafis dari yang ditunjukkan pada Gambar8 dan Gambar 9. Sehingga dari hasil pengujian yang diperoleh kesimpulan yang dapat diambil hanya dapat dilakukan secara kuantitatif.

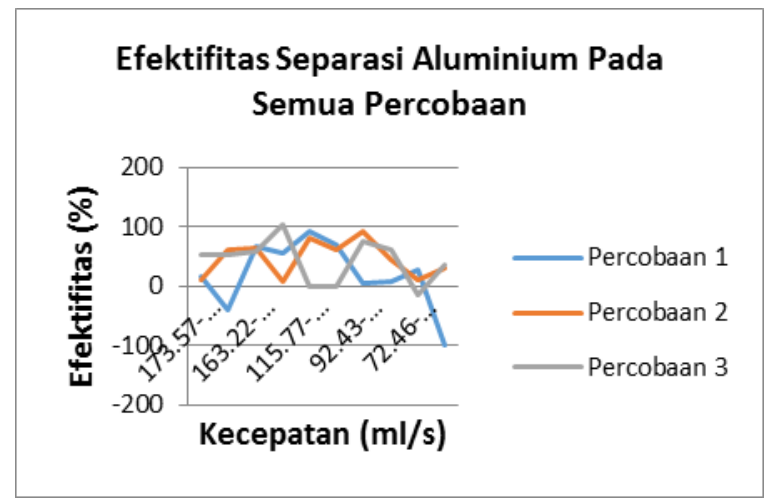

Gambar 9. Efektifitas Separasi Aluminium Pada Semua Percobaan

\subsection{Analisa Efektifitas Separasi Alumunium}

Untuk menentukan nilai efektifitas separasi aluminium, terlebih dahulu kita tentukan 3 posisi teratas dari setiap percobaan separasi. Persentase indikator diberikan pada tiga nilai tertinggi dari efektifitias separasi aluminium sebesar 25 untuk urutan pertama, 20 untuk yang kedua dan 18 untuk yang ketiga. Dari data yang diperoleh ditentukan setiap tiga nilai teratas dari nilai efektifitas separasi, yang ditunjukkan pada Tabel 5 untuk aluminium dan Tabel 6 untuk tembaga.
Tabel 5. Perhitungan Efektifitas Separasi Al

\begin{tabular}{|c|c|c|c|}
\hline Peringkat & $\eta$ & $\%$ IN & Posisi \\
\hline P11 & 92.85 & 25 & 5 \\
\hline P12 & 67.5 & 20 & 3 \\
\hline P13 & 56.25 & 15 & 4 \\
\hline P21 & 92.3 & 25 & 7 \\
\hline P22 & 80 & 20 & 5 \\
\hline P23 & 64.28 & 15 & 3 \\
\hline P31 & 104 & 25 & 4 \\
\hline P32 & 76 & 20 & 7 \\
\hline P33 & 57.14 & 15 & 3 \\
\hline
\end{tabular}

Tabel 6. Perhitungan Efektifitas Separasi $\mathrm{Cu}$

\begin{tabular}{|c|c|c|c|}
\hline Peringkat & $\eta$ & $\%$ IN & Posisi \\
\hline P11 & 129.62 & 25 & 9 \\
\hline P12 & 126.82 & 20 & 1 \\
\hline P13 & 125.58 & 15 & 8 \\
\hline P21 & 132.6 & 25 & 8 \\
\hline P22 & 102 & 20 & 3 \\
\hline P23 & 100 & 15 & 9 \\
\hline P31 & 1046.15 & 25 & 10 \\
\hline P32 & 326.92 & 20 & 8 \\
\hline P33 & 178.78 & 15 & 9 \\
\hline
\end{tabular}

\section{KESIMPULAN DAN SARAN}

Dari analisa yang dilakukan menunjukkan bahwa Alumunium dan Tembaga dapat secara optimal diseparasi pada flow rate $(165,25-167,77) \mathrm{ml} / \mathrm{s}$. Efektifitas separasi Alumunium paling efektif terletak pada posisi bukaan katup ke 3 dengan flow rate $(163,22-168,87) \mathrm{ml} / \mathrm{s}$ dan efektifitas separasi tembaga paling efektif berada pada flow rate $(83,5$ 85) $\mathrm{ml} / \mathrm{s}$.

\section{DAFTAR PUSTAKA}

[1] Y. S. Helmi Guntoro, Erik Haritman, "Rancang Bangun Magnetic Door Lock Menggunakan Keypad Dan Solenoid Berbasis Mikrokontroler Arduino Uno," Electrans, Vol. 12, Pp. 10, 2013.

[2] "Pengertian Ukuran Mesh Dan Konversinya," 03 Desember 2018, 2018. G. D. Gordon K. 
Van Vleck, Don L. Blubaugh, Michael Silva, James F. Davis, "Placer Gold Recovery Methods," C. D. O. C. D. O. M. A. Geology, Ed., California Department Of Conservation Division Of Mines And Geology, 1986.

[3] M. P. Jones, "A Continuous, Laboratory-Size Density Separator For Granular Materials," 1965.

[4] Y. S. Helmi Guntoro, Erik Haritman, "Rancang Bangun Magnetic Door Lock Menggunakan Keypad Dan Solenoid Berbasis Mikrokontroler Arduino Uno," Electrans, Vol. 12, Pp. 10, 2013.

[5] H. T. Sularso, Pompa \& Kompresor, 7 Ed., Jakarta: Pt Pradnya Paramita, 2000.

[6] M. S. Prof. Dr. Abd Wahid Wahab, Dr. Nursiah La Nafie, M.Sc, Metode Pemisahan Dan Pengukuran 2 (Spektrometri Dan Elektrofotometri), Makassar: Program Studi Kimia Fakultas Matematika Dan Ilmu Pengetahuan Alam Universitas Hasanuddin, 2014.

[7] Salman, "Penangkapan Partikel Timah Dari Alluvial Tambang Timah Dengan Metode Vortex," Jurusan Teknik Mesin Fakultas Teknik Universitas Andalas, Padang, 2011.

[8] T. S. Muhammad Budi Nur Rahman, "Pengaruh Sudut Water Sprayer Dan Tekanan Air Dalam Sprayer Pump Terhadap Hasil Serbuk Alumunium Pada Proses Atomisasi Air," Ilmiah Semesta Teknika, Vol. 9, Pp. 13, 2006.

[9] A. Maulana, "Mengenal Arduino Uno Lebih Rinci," Aozon.Blogspot.Com, 2014.

[10] A. Munandar. "Liguid Crystal Display (Lcd) 16 X 2," 08 Desember, 2018. 